\title{
The Intuitive Manager and the Concept of Strategic Leadership
}

Ph.D. Kamila Malewska Poznań University of Economics

Ph.D. Maja Sajdak Poznań University of Economics

\section{Introduction}

Changes in the managerial environment, which are taking place at an increasingly fast pace and are becoming less and less predictable, are leading to a situation where information is becoming quickly outdated, and in some cases it is already not very reliable by the time of its acquisition by managers. Moreover, the amount of information that managers acquire is increasing every year, which means that the level of saturation brings about changes in the decision-making model: from decision-making under conditions of incomplete information towards conditions of information overload (Kowalewski 2012, p. 504). Decision-makers often work under time pressure and are unable to carry out time-consuming analysis. They also use information processing procedures typical of rational decision-making processes. This leads to the need for employing intuition, which allows for an analysis of significant information resources and the identification of those that are essential from the perspective of decision-making. Therefore, one can assume that nowadays the concept of intuitive management seems to be an important 
source of gaining and maintaining a competitive advantage. When considering the issue of competitive advantage, the role of leadership in this process cannot be overlooked. Often, the ability to transfer visionary leadership to operational management determines the success of the organization in the market. In the literature on the subject, this ability is referred to as strategic leadership.

The aim of this paper is to show the consistency of an intuitive manager's traits and skills and a strategic leader's attributes. The paper consists of three main parts. The first one presents the nature and evolution of the concept of leadership and contrasts the role of strategic leaders with the operational requirements of modern organizations. In the second part, we attempt to define the concept of intuition and characterize an intuitive manager. In the last section of the paper, a strategic leader's attributes and an intuitive manager's skills and characteristics are analyzed in order to show how these two categories converge.

\section{Strategic leadership and operational requirements of the modern enterprise}

Strategic leadership is the ability to combine visionary operational management, i.e., the spread of ideas, but also the ability to embed these ideas in company operations taking into account their limitations. Strategic leadership integrates philosophical thoughts (with the focus on the overall vision, intuition, beliefs and values) with company realities (resource constraints - material and immaterial). Introducing the concept of strategic leadership, G. Rowe and M. Nejad define it as a synergic combination of visionary leadership and management, with the primary focus on ethical behaviour and decisions based on values. Strategic leadership requires the operational supervision of daily activities, and a simultaneous strategic, long-term responsibility. It assumes the formulation and implementation of strategies for unforeseen events and a consistent implementation of long-term objectives to ensure survival and development. Its assumptions include both strategic and financial control, but an emphasis is put on the feasibility of strategic plans. Strategic leadership involves the exchange of hidden knowledge at individual and organizational levels. Human resources management should be based on training that enables the development of highly skilled, motivated, trustworthy people working in a team (Rowe, Nejad 2009, pp. 2-6).

K. Grzesik (2011, p. 89) indicates that strategic leadership consists in the ability to cope with situations that are difficult to predict and to deal with important changes in the environment. This kind of leadership means continuous 
adjustments, reorientation and organizational improvement. The essence of strategic leadership is making changes, starting from the direction of company operations to developing a vision for the future and determining the necessary steps needed to implement this vision.

It is difficult to imagine the success of Ford, Microsoft, Apple or Polsat without their founders - Henry Ford, Bill Gates, Steve Jobs and Zygmunt Solorz-Żak. The success or failure of a company depends on its leader this is why it is so important how strategic leadership is perceived and how it is implemented. All mentioned above founders share at least one important thing in common - a wide business vision (frequently in the beginning unreal vision) that was implemented in business reality including complete use of business resources and development potential.

A special kind of business is family business where the conditions for leader development are better than anywhere else. The more the owners sphere is connected to the management sphere the easier it is to fully identify oneself with the company. Identifying oneself with the company is the main motivation of a family business leader. Such leaders are often passionate with a mission. They act on intuition that enhanced by charisma, experience, involvement and courage leads to success like in case of: Jan Kulczyk, Zygmunt Solorz-Żak or Wojciech Kruk. The primary objective of a family business is to survive which is also the main motivation and delivers job satisfaction. On one hand strategic leadership in family business provides development and business value increase on the other hand it helps to maintain permanent family relations (May, Lewandowska 2014, pp 194-200).

G. Avery (2009, pp. 38-39)presents four sets of ideas which he described as classical, transactional, visionary and organic leadership. Time is the basic dimension in which the analysed issues can be put, and which helped the author to order it chronologically. They also vary in terms of their leadership basis, which covers the range from dominance (in the case of traditional leaders) to a complete departure from individual, formal leadership in the paradigm of organic leadership (as well as in the strategic one). As the leadership types evolve from classical to organic ones, the voluntary involvement of employees is also growing, as opposed to forced subordination. Another criterion that differentiates the analysed paradigms is attitudes to the leader's vision. The paradigms have been ordered according to the growing dependence on the leader's vision. 
Table 1. Leadership paradigms

\begin{tabular}{|c|c|c|c|c|}
\hline $\begin{array}{l}\text { Leadership } \\
\text { paradigms }\end{array}$ & Classic & Transactional & Visionary & Organic \\
\hline $\begin{array}{l}\text { The most } \\
\text { important } \\
\text { period of time }\end{array}$ & $\begin{array}{l}\text { From antiquity } \\
\text { to the } 1970 \text { s }\end{array}$ & $\begin{array}{l}\text { From the } 1970 \text { s to the } \\
\text { mid-80s }\end{array}$ & $\begin{array}{l}\text { From the mid-80s } \\
\text { to } 2000\end{array}$ & After 2000 \\
\hline $\begin{array}{l}\text { Leadership } \\
\text { basis }\end{array}$ & $\begin{array}{l}\text { The leader's } \\
\text { dominance } \\
\text { based on respect } \\
\text { and authority, } \\
\text { based on } \\
\text { commands and } \\
\text { control }\end{array}$ & $\begin{array}{l}\text { The impact on the } \\
\text { group members } \\
\text { exerted in face to } \\
\text { face contact, with } \\
\text { their opinions and } \\
\text { feelings taken into } \\
\text { account. Creating the } \\
\text { right environment for } \\
\text { management }\end{array}$ & $\begin{array}{l}\text { Emotions - the } \\
\text { leader inspires } \\
\text { group members }\end{array}$ & $\begin{array}{l}\text { Shared } \\
\text { interpretation } \\
\text { of the group } \\
\text { environment. } \\
\text { Leaders may } \\
\text { emerge from the } \\
\text { group instead of } \\
\text { being formally } \\
\text { appointed }\end{array}$ \\
\hline $\begin{array}{l}\text { The source } \\
\text { of group } \\
\text { members' } \\
\text { involvement }\end{array}$ & $\begin{array}{l}\text { The fear of } \\
\text { or respect for } \\
\text { leaders; an } \\
\text { effort made to } \\
\text { get a reward } \\
\text { or to avoid } \\
\text { punishment }\end{array}$ & $\begin{array}{l}\text { Negotiating awards, } \\
\text { agreements and } \\
\text { expectations }\end{array}$ & $\begin{array}{l}\text { Shared vision; the } \\
\text { leader's charisma; } \\
\text { individualized } \\
\text { approach to } \\
\text { group members }\end{array}$ & $\begin{array}{l}\text { Supporting values } \\
\text { and processes } \\
\text { common to the } \\
\text { whole group; } \\
\text { willingness to } \\
\text { develop self- } \\
\text { identification }\end{array}$ \\
\hline Vision & $\begin{array}{l}\text { The leader's } \\
\text { vision is not } \\
\text { necessary } \\
\text { to exact the } \\
\text { obedience of } \\
\text { group members }\end{array}$ & $\begin{array}{l}\text { The vision is not } \\
\text { necessary and may } \\
\text { never be articulated }\end{array}$ & $\begin{array}{l}\text { The vision is the } \\
\text { most important } \\
\text { element; group } \\
\text { members can } \\
\text { contribute to the } \\
\text { leader's vision }\end{array}$ & $\begin{array}{l}\text { The vision is } \\
\text { created in the } \\
\text { group; the vision } \\
\text { is an important } \\
\text { element of the } \\
\text { organization } \\
\text { culture }\end{array}$ \\
\hline
\end{tabular}

Source: Avery 2009, p. 38

In visionary leadership, the leader appeals to emotions and inspires group members to greater achievements. The leader's charisma, the shared vision and an individual approach to the group are the source of the members' dedication and commitment. In contrast, the basis of organic leadership is communication. The leadership emerges in the relationships between the changing conditions and the organization members who interpret the environment together. Members of the group create the vision, values and processes, and these are shared. 
In the organic leadership paradigm the group as a whole is the most important. Strategic leadership which combines the features of both these concepts, seems to be an ideal form for businesses in which the need to adapt to permanent changes requires the considerable commitment of employees and good communication, which provides speed and efficiency in the implementation of assigned tasks (Sajdak 2013).

Table 2. Characteristics of strategic leadership in the context of the requirements for the functioning of a modern organization

\begin{tabular}{|c|c|c|}
\hline Criteria & $\begin{array}{c}\text { Characteristics of modern } \\
\text { enterprises }\end{array}$ & $\begin{array}{c}\text { Characteristics of strategic } \\
\text { leadership }\end{array}$ \\
\hline $\begin{array}{l}\text { Organizational } \\
\text { structure }\end{array}$ & $\begin{array}{l}\text { Flat organizational structure, team } \\
\text { management }\end{array}$ & $\begin{array}{l}\text { Employees' self-control, which } \\
\text { gives them a sense of purpose and } \\
\text { autonomy, limiting the project or } \\
\text { group leaders' supervision }\end{array}$ \\
\hline $\begin{array}{l}\text { Decentralization of } \\
\text { authority }\end{array}$ & $\begin{array}{l}\text { Autonomy and empowerment, } \\
\text { teams of employees form the } \\
\text { structure of network interactions } \\
\text { between autonomous entities }\end{array}$ & $\begin{array}{l}\text { Leaders emerge not only at the top } \\
\text { of the structure, but are scattered } \\
\text { throughout the organization, their } \\
\text { roles overlapping the functions and } \\
\text { levels of the organization }\end{array}$ \\
\hline Status of employees & $\begin{array}{l}\text { Learning employees, versatility, } \\
\text { employees' involvement, a wide } \\
\text { range of skills }\end{array}$ & $\begin{array}{l}\text { Strategic leaders are able to motivate } \\
\text { and inspire creative activities and } \\
\text { innovative ideas }\end{array}$ \\
\hline $\begin{array}{l}\text { Involvement of } \\
\text { employees }\end{array}$ & $\begin{array}{l}\text { Full empowerment of employees } \\
\text { - their ideas and knowledge are } \\
\text { often used }\end{array}$ & $\begin{array}{l}\text { Self-organization of employees, } \\
\text { "being their own leaders" }\end{array}$ \\
\hline Leadership style & $\begin{array}{l}\text { Management based on cooperation, } \\
\text { leadership is sensitive to change } \\
\text { and willing to improve }\end{array}$ & $\begin{array}{l}\text { Willingness to form self-improving } \\
\text { teams, reliance on a common vision } \\
\text { and deeply rooted core values, as } \\
\text { well as a sense of responsibility for } \\
\text { their own actions }\end{array}$ \\
\hline
\end{tabular}

Source: own materials

Strategic leadership is one of the main research directions in mainstream strategic management. For many years, it has been hotly debated among certain groups of theoreticians and practitioners of management; however, it should be emphasized that the views on this subject were and still are quite diverse. 
The reason for such divergent opinions is probably the fact that the essence of leadership is still one of the least recognized issues in strategic management. J. Polowczyk (2011) identifies three psychological issues that are the most frequently described in the literature on strategic leadership. These are: intuition, the core of self-evaluation, and passion. In the subsequent part of the paper the issue of managerial intuition, a key component of strategic leadership, will be discussed in more detail.

\section{The essence of intuition}

An analysis of economic practice, and especially of managers' effectiveness, indicates that full information is not a sufficient condition for making the right decisions. An inverse relationship can be observed here: the greater the wealth of information that managers have, the more reduced their effectiveness and ability to make optimal decisions. This is due to the weakening and suppressing of their intuitive potential, which is often replaced by analytical work of little value (Hayasi 2001, p. 61).

As a consequence of technological development, the acquisition, processing, transmission and storage of data and information has ceased to be a major problem. However, the ability to select and identify information relevant to the decision-making process is a much desired skill. It should be emphasized that the speed of decision-making is gaining importance. Time pressure and the large amounts of information that decision-makers are forced to analyse are not conducive to making quick and accurate decisions (Jamieson, Hayland 2006, p. 55).

The trends mentioned above are the reason why intuition is becoming increasingly important in the management of companies, especially in decisionmaking. Many decision-makers do not appreciate the role of premonition, experience or anticipation skills in doing business, while these are inextricably linked to the use of intuition by managers. According to E. Dane and M. Pratt, people have a natural ability to select information and make a rapid and effective synthesis. However, this process can be disturbed by the use of formalized information processing procedures, which in turn often reduce the effectiveness of these activities (Dane, Pratt 2007, p. 33).

It is worth pointing out that the use of intuition is of particular importance, especially at the strategic level, when decision-makers are forced to solve individual, complex, and unstructured problems (Clarke, Mackaness 2001, p. 148; Shapiro, Spence 1997, p. 63). Empirical studies show that top managers 
do in fact use their intuitive potential in the decision making process. The main functions that intuition fulfils in this process are the following (Agor 1998, pp. 206-207):

- creative (generating a significant number of unconventional solutions),

- integrative (allows for a smooth transition between the various stages of the decision-making process),

- informative (allows the filling of the gap in an absence of information or the analysis of large amounts of information under conditions of information noise).

Determining the role and importance of intuition in management is the first and necessary step in defining this concept. It was derived from the medieval Latin word "intuitio", which means "whisper" or "premonition". The synonyms of "intuition" are words and phrases such as creative imagination, premonition, anticipation, instinctive knowledge, a sixth sense, and a sudden insight. It is a psychological concept meaning an immediate act of understanding or perception of a fact, existence, or the relationship between two phenomena or results (Fazlagić 2012).

Therefore, it can be considered that intuition is a way of acquiring knowledge and it represents the thought process which results in the quick adjustment of a given situation, problem or phenomenon to previously known templates, patterns or relationships. It takes the form of a sudden flash of inspiration resulting in finding a solution to a problem or an answer to a question (Kowalewski 2012, p. 501).

In the literature on the subject, the concept of intuition is not clearly and precisely defined. This is due to the interdisciplinary nature of this concept (it has been primarily considered on the grounds of psychology, philosophy and management) and the aforementioned variety of terms used to define intuition. It is possible to identify some common threads or ideas by analysing the definitions of intuition proposed by the authors in the field of management (table 3).

Intuition is often confused or identified with a premonition, especially with an emotional or instinctive background. A premonition is a conviction taking the form of feelings or emotions suggesting that something may happen (it usually has a negative connotation). Intuition, in turn, is a thought process taking place in the subconscious, which is not subject to control. It is only possible to accept them and put intuitive solutions into practice, or question and reject them. It is a creative process characterized by a much higher level of abstraction than the process of logical thinking. The result of using intuition is knowledge acquired without the need for rational reasoning, while instinct suggests activities 
that have a strong genetic predisposition. Brain research shows that intuition is a kind of good conduct guideline which occurs in mental processes, just before creative solutions are generated (Fazlagić 2012).

\section{Table 3. Common threads in defining the concept of intuition}

\begin{tabular}{l|l}
\hline \multicolumn{1}{c|}{ Authors } & \multicolumn{1}{c}{ Common threads in defining the concept of intuition } \\
\hline $\begin{array}{l}\text { C.G. Jung; K.W. Wild; K.S. } \\
\begin{array}{l}\text { Bowers; D.A. Shirley and J. } \\
\text { Spence; R. M. Hoghard; M.H. } \\
\text { Raidl; T.L. Lubarr }\end{array}\end{array}$ & $\begin{array}{l}\text { - Intuition is a part of the subconscious mind (it is embedded } \\
\text { deeply in the human mind and it is a spontaneous and } \\
\text { subconscious action) }\end{array}$ \\
\hline $\begin{array}{l}\text { R. Rorty; D. Kahneman; E. Dane } \\
\text { and M. Pratt }\end{array}$ & $\begin{array}{l}\text { Intuitive decisions are characterized by high speed (they } \\
\text { are immediate and lead to direct associations, which is } \\
\text { considered to be one of the main advantages of the intuitive } \\
\text { decision-making process) }\end{array}$ \\
\hline $\begin{array}{l}\text { L.A. Burke; M.K. Miller; M.D. } \\
\text { Liebermann }\end{array}$ & $\begin{array}{l}\text { Intuitive actions are based on previous experience } \\
\text { (it is assumed that there is a linear relationship between } \\
\text { managers' intuitive potential and their knowledge and } \\
\text { experience), each intuitive decision is unique and subjective, } \\
\text { much the same as the unique experience of the decision- } \\
\text { maker }\end{array}$ \\
\hline $\begin{array}{l}\text { m.S. Bruner; D.G. Myers } \\
\text { M.R. Westcott; J.H. Razoni }\end{array}$ & $\begin{array}{l}\text { Intuitive decision-making is associated with the decision- } \\
\text { maker's conviction that a rational analysis is useless or its } \\
\text { usefulness is limited }\end{array}$ \\
\hline $\begin{array}{l}\text { Intuitive decision-making process stems from insufficient } \\
\text { information, which is a prerequisite for rational analysis }\end{array}$ \\
\hline
\end{tabular}

Source: own study based on Dane, Pratt 2007, p. 35

It should be emphasized that decision-makers who use intuition in the decision-making process possess certain traits and skills, as well as specific working and thinking styles. Referring to an intuitive manager's characteristics and competences, attention should be primarily paid to the following (Malewska 2010, pp. 334-351):

- ability to analyse and synthesize large amounts of information and to identify what is essential from the point of view of the decision to be made,

- ability to fill the information gap by reference to personal knowledge or previous experience, 
- decision-making readiness (the ability to make decisions under conditions of both a lack and excess of information),

- generating innovative solutions,

- a unique approach to analysed problems,

- motivation to seek the best solution,

- willingness to take risk (taking action even in the absence of the necessary information).

Analysing an intuitive manager's working style, one can see that it is characterized primarily by a lack of sequential actions (he/she does not go through the various stages of the classic decision-making process). Apparently, the observer gets the impression that the action seems to be quite chaotic. Besides, during the problem solving phase, one can distinguish different stages associated with varying levels of involvement and the intensity of work undertaken by the decision-maker. After a period of considerable intellectual effort, one can observe a decrease of interest in the problem. Intuitive managers work better when informal ties dominate in their teams of co-workers. Intuitive managers' effectiveness increases when they cooperate with other managers who prefer similar working and thinking styles.

\section{The compatibility of leadership skills and an intuitive manager's characteristics}

P. Schoemaker, S. Kupp and S. Howland (2013) carried out a study on a group of more than twenty thousand senior managers. Based on the results of their research, they have determined six skills which leaders should master in order to think strategically and function effectively in a turbulent and hostile environment. These include the ability to anticipate, the willingness to take on challenges, the ability to interpret, the ability to make decisions, the ability to determine common areas of activity, and the ability to learn. The authors also recognize the fact that being a strategic leader means identifying their own weaknesses within these six skills and correcting them. The study also indicated that proficiency in one of the skills cannot compensate for a deficit in another and, therefore, attention should be paid to the optimization of all six essential attributes of a strategic leader.

J. Polowczyk (2011) indicates that intuition is one of the key elements for effective strategic leadership. Therefore, this means that a strategic leader's traits should be consistent with the characteristics and skills of managers who have and use their intuitive potential in practice. In the table below, we attempted 
to put together the attributes and characteristics of strategic leadership and intuitive managerial competences in order to demonstrate their convergence.

Table 4. The attributes of strategic leadership and intuitive managerial characteristics and competences

\begin{tabular}{|c|c|c|}
\hline Traits & Description & The intuitive manager's traits and competences \\
\hline $\begin{array}{l}\text { Ability to } \\
\text { anticipate }\end{array}$ & $\begin{array}{l}\text { This trait is most commonly } \\
\text { used to predict phenomena } \\
\text { and identify opportunities } \\
\text { and threats through the use } \\
\text { of weak signals coming from } \\
\text { both inside and outside the } \\
\text { organization. }\end{array}$ & $\begin{array}{l}\text { - Ability to perform a comprehensive analysis of } \\
\text { competitors } \\
\text { - Ability to identify new trends, customer } \\
\text { needs, emerging opportunities in the business } \\
\text { environment, threats that should be neutralized } \\
\text { - Courage and confidence in action (Bieniok, } \\
\text { Halama, Ingram 2006, p 92) }\end{array}$ \\
\hline $\begin{array}{l}\text { Willingness } \\
\text { to take on } \\
\text { challenges }\end{array}$ & $\begin{array}{l}\text { Strategic leaders always } \\
\text { question the status quo, } \\
\text { they set up challenges for } \\
\text { themselves and others, they } \\
\text { encourage others to analyse } \\
\text { divergent points of view. This } \\
\text { all requires patience, courage } \\
\text { and an open mind }\end{array}$ & $\begin{array}{l}\text { - Perseverance in pursuing goals (an intuitive } \\
\text { manager is never fully satisfied with any generated } \\
\text { solution and, therefore, he/she constantly looks for } \\
\text { better solutions) } \\
\text { - Internal motivation for action (an intuitive } \\
\text { manager is motivated to seek the optimal solution) } \\
\text { (Woiceshyn 2009, p 311) } \\
\text { - Using all available sources of information: } \\
\text { objective data, knowledge and the personal } \\
\text { experience of both managers and others, but also } \\
\text { taking into account the intuition, feelings and } \\
\text { emotions that accompany the decision-making } \\
\text { process (Kutschera, Ryan, 2009, pp 17-18) } \\
\text { - Ability to generate innovative and unconventional } \\
\text { solutions (a unique approach to problem solving, } \\
\text { which is not a continuation or extension of } \\
\text { previously applied solutions) (Agor 1998, p 163). }\end{array}$ \\
\hline $\begin{array}{l}\text { Ability to } \\
\text { interpret }\end{array}$ & $\begin{array}{l}\text { Ability to solve complex } \\
\text { problems, to synthesize and } \\
\text { interpret information }\end{array}$ & $\begin{array}{l}\text { - Ability to analyse and synthesize large amounts of } \\
\text { information and identify that which is necessary } \\
\text { from the perspective of the decision being made } \\
\text { (Agor 1998, p 163) } \\
\text { - Using a holistic, synthetic approach allowing for } \\
\text { the consideration of multiple threads of ideas } \\
\text { simultaneously, which is desirable in solving } \\
\text { complex and unstructured problems (Agor 1998, } \\
\text { p 262) } \\
\text { - Focusing attention on facts, but at the same time } \\
\text { keeping an open mind to intuitive hints and } \\
\text { hunches (Kutschera, Ryan 2009, pp 17-18) }\end{array}$ \\
\hline
\end{tabular}




\begin{tabular}{|c|c|c|}
\hline $\begin{array}{l}\text { Ability } \\
\text { to make } \\
\text { decisions }\end{array}$ & $\begin{array}{l}\text { The ability to make decisions } \\
\text { requires the courage to } \\
\text { take responsibility for the } \\
\text { measures implemented. This } \\
\text { is quite difficult because, due } \\
\text { to unforeseen changes in the } \\
\text { environment, the effects of } \\
\text { our actions cannot always } \\
\text { be precisely defined. The } \\
\text { decision-making process often } \\
\text { takes place under such difficult } \\
\text { conditions as a lack of time } \\
\text { and information. Decision- } \\
\text { making is a formal process } \\
\text { taking into account short-term } \\
\text { and long-term goals }\end{array}$ & $\begin{array}{l}\text { - The need for action in a changing environment, } \\
\text { resulting in constant readiness for decision- } \\
\text { making } \\
\text { - Ability to solve a decision-making problem, } \\
\text { even in the absence of information by filling the } \\
\text { information gap using intuition } \\
\text { - Acceptance of risk and uncertainty (willingness to } \\
\text { take risks) } \\
\text { - Ability to function in a risky and uncertain } \\
\text { environment (Harper 1998, p 145) }\end{array}$ \\
\hline $\begin{array}{l}\text { Ability } \\
\text { to find } \\
\text { common } \\
\text { areas of } \\
\text { cooperation }\end{array}$ & $\begin{array}{l}\text { Strategic leaders must have } \\
\text { the ability to find areas of } \\
\text { dialogue with stakeholders } \\
\text { representing different } \\
\text { interests and perspectives }\end{array}$ & $\begin{array}{l}\text { - Taking into account opinions, knowledge and } \\
\text { experience of others, so that decisions are } \\
\text { characterized by a higher level of acceptability } \\
\text { - Evolved emotional awareness associated with the } \\
\text { ability to recognize our own emotions and those } \\
\text { of others. This ability enables us to find common } \\
\text { areas of dialogue with other stakeholders [Shaw } \\
\text { 2010, pp 77-79] }\end{array}$ \\
\hline $\begin{array}{l}\text { Ability to } \\
\text { learn }\end{array}$ & $\begin{array}{l}\text { Strategic leaders are in } \\
\text { the centre of the learning } \\
\text { processes in an organization. } \\
\text { They promote a type of } \\
\text { culture based on the constant } \\
\text { search for new knowledge } \\
\text { and better solutions, learning } \\
\text { from both successes and } \\
\text { failures }\end{array}$ & $\begin{array}{l}\text { - Generating solutions that are seemingly } \\
\text { unresolvable, decision-making problems } \\
\text { - Solving problems in the absence of sufficient } \\
\text { information } \\
\text { - Proposing individual, creative and unique } \\
\text { solutions, allowing for the continuous } \\
\text { improvement of managerial skills and increasing } \\
\text { the stock of knowledge (intuitive managers might } \\
\text { be called "creative thinkers" or "champions of } \\
\text { change") (Agor 1987, p 163) } \\
\text { - There is a linear relationship between an intuitive } \\
\text { manager's potential and experience (Klain, 2003; } \\
\text { Hogarth, 2001, pp 9-21). Therefore, one can assume } \\
\text { that an intuitive manager should continually learn } \\
\text { (acquire, create, store and share knowledge) in } \\
\text { order to strengthen his/her intuition } \\
\text { - Preference for informal relations, which promote } \\
\text { sharing hidden knowledge through socialization, } \\
\text { according to the knowledge conversion process } \\
\text { formulated by Nonaka and Takeuchi (Nonaka, } \\
\text { Takeuchi 2000) }\end{array}$ \\
\hline
\end{tabular}

Source: own study based on Schoemaker, Kupp, Howland 2013 
Making a synthesis of the above table, a convergence can be seen between the strategic leadership attributes proposed by P. Schoemaker, S. Kuppa and S. Howland and an intuitive manager's traits and skills. According to these authors, these attributes should enable a manager to think effectively and strategically, and to operate efficiently in a changing and unstable environment. The use of intuition in decision making is necessitated by a complex and unpredictable environment, and those conditions relating to time pressure, uncertainty, and an excess or a lack of information, under which contemporary decision-makers have to take decisions. Consequently, one can assume that strategic leaders should possess, improve and effectively use their intuitive potential.

\section{Summation}

Modern organizations operate in a rapidly changing environment, which deepens the complexity and uncertainty in decision-making at all levels of management. The pace of changes taking place simultaneously in many areas and the need to adapt to them is a huge challenge for members of any organization, especially at the strategic level. Before they have managed to fully adjust to one change, they face another, which brings new uncertainties and increases the complexity of decision-making problems. The great challenge for leaders is to work under rapidly changing conditions. Time pressure and information overload leading to communication chaos do not help managements to carry out reliable decision-making processes. Consequently, they need to turn to intuition, which enables them to analyse significant information resources and identify these that are crucial from the perspective of decision-making.

In the context of the resource-based approach to strategic management, one of the main directions of research is strategic leadership (Polowczyk 2011, p. 3-7), which integrates the characteristics resulting from the paradigm of visionary leadership (as well as charismatic and transformational ones) and the concept of organic leadership (Avery 2009, pp. 39-57). An in-depth analysis of a strategic leader's attributes as well as an intuitive manager's characteristics and skills has shown that these two categories converge.

This paper discusses in detail the managerial intuitive potential seen from the perspective of the six skills which leaders should master in order to think strategically and function effectively in a rough and hostile environment. Reference has been made to the skill of anticipation, the willingness to take on challenges, the ability to interpret, the ability to make decisions, the ability to find common areas of cooperation, and the ability to learn. The conclusions 
clearly demonstrate the compatibility of a strategic leader's attributes and an intuitive manager's competences and their key role in the efficient functioning of modern enterprises.

\section{Summary}

The Intuitive Manager and the Concept of Strategic Leadership The aim of this paper is to show the consistency of an intuitive manager's traits and skills and a strategic leader's attributes. The paper consists of three main parts. The first one presents the nature and evolution of the concept of leadership and contrasts the role of strategic leaders with the operational requirements of modern organizations. In the second part, we attempt to define the concept of intuition and characterize an intuitive manager. In the last section of the paper, a strategic leader's attributes and an intuitive manager's skills and characteristics are analyzed in order to show how these two categories converge.

Key words: intuitive manager, strategic leadership.

\section{Streszczenie}

Intuicyjny menedżer a koncepcja strategicznego przywództwa

Celem referatu jest przedstawienie spójności między cechami i umiejętnościami intuicyjnego menedżera a atrybutami strategicznego przywódcy. Referat składa się z trzech zasadniczych części. W pierwszej kolejności zaprezentowano istotę i ewolucję koncepcji przywództwa oraz zestawiono role strategicznego przywódcy z wymogami funkcjonowania współczesnych organizacji. Następnie podjęto próbę zdefiniowania pojęcia intuicji oraz scharakteryzowania intuicyjnego menedżera. W ostatniej części referatu poddano analizie atrybuty strategicznego przywódcy oraz cechy i umiejętności intuicyjnego menedżera w celu ukazania zbieżności między tymi kategoriami.

\section{Słowa}

kluczowe: intuicyjny menedżer, przywództwo strategiczne. 


\section{References}

1. Agor W.H. (1998), Intuicja w organizacji. Jak twórczo przewodzić i zarządzać, Wydawnictwo Personalnej Szkoły Biznesu, Kraków.

2. Avery G. (2009), Przywództwo w organizacji. Paradygmaty i studia przypadków, Polskie Wydawnictwo Ekonomiczne.

3. Bieniok H.,Halama H, Ingram M. (2006), Podejmowanie decyzji menedżerskich, Wydawnictwo Akademii Ekonomicznej w Katowicach, Katowice.

4. Clarke I., Mackaness W. (2001), Management intuition; An Interpretative Account of Structure and Content of Decision Schemas Using Cognitive Maps, "Journal of Management Studies", Vol. 38. Issue 2, March.

5. Dane E., Pratt M. (2007), Exploring Intuition and its Role in Managerial Decision Making, "Academy of Management Review", vol. 32, no.1.

6. Fazlagić J., Intuicyjne zarządzanie, www.abc.com.pl, portal internetowy Wydawnictwa Wolters Kluwer (data dostępu: 12.04.2012).

7. Grzesik K. (2011), Wptyw przywództwa strategicznego na trwałość i rozwój przedsiębiorstwa, [w:] J. Skalik (red. nauk.), Zmiana warunkiem sukcesu. Przełamywanie barier rozwoju $i$ wzrostu przedsiębiorstw, Wydawnictwo Uniwersytetu Ekonomicznego we Wrocławiu, Wrocław.

8. Harper S.C. (1998), Intuicja: Co odróżnia dyrektorów od kierowników niższych szczebli, W.H. Agor (red), Intuicja w organizacji. Jak twórczo przewodzić i zarządzać, Wydawnictwo Profesjonalnej Szkoły Biznesu, Kraków.

9. Hayashi A.M. (2007), When to trust your gut, "Harvard Business Review”, vol. 32, no. 1.

10. Jamieson K., Hayland P. (2006), Good Intuition or Fear of Uncertainty, "Informing Science Journal", vol. 9.

11. Hogarth R.M. (2001), Educating intuition, University of Chicago Press, Chicago.

12. Klein G. (2003), Intuition at work: Why developing your gut instincts will make you better at what you do?, Currency, Doubleday, New York.

13. Kowalewski K. (2012), .Zarzadzanie intuicyjne w przedsiębiorstwach pótnocno-wschodniej Polski (wyniki badań), Zeszyty Naukowe Uniwersytetu Szczecińskiego, nr 737,

14. Kutschera I., Ryan M.H. (2009), Implications of Intuition for Strategic Thinking: Practical Recommendations for Gut Thinkers, "Advanced Management Journal", Summer.

15. Malewska K. (2010), Intuicja w procesie podejmowania decyzji menedżerskich, praca zbiorowa pod red. J. Stankiewicz, Społeczne wymiary zarzadzania nowoczesnymi przedsiębiorstwami : ludzie - kultura organizacji - społeczna odpowiedzialność, Wydawnictwo Uniwersytetu Zielonogórskiego, Zielona Góra.

16. May P., Lewandowska A. (2014), Stawka większa niż biznes, Strategie rozwoju firm rodzinnych, Oficyna a Wolters Kluwer Business, Warszawa. 
17. Nonaka I, Takeuchi H. (2000), Kreowanie wiedzy w organizacji, Polska Fundacja Promocji Kadr, Warszawa.

18. Polowczyk J. (2011), Przywództwo strategiczne w świetle osiagnięć psychologii, Przegląd Organizacji nr 1.

19. Rowe G., Nejad H. (2009), Strategic leadership: short term stability and longterm viability, "Ivey Business Journal", vol.73, issue 5.

20. Sajdak M. (2013), Przywództwo strategiczne w zwinnym przedsiębiorstwie, Organizacja i Zarządzanie, nr 49, Zeszyty Naukowe Politechniki Łódzkiej, Łódź.

21. Shapiro S., Spence M.T. (1997), Managerial Intuition: A conceptual and Operational Framework, "Business Horizons", January-February.

22. Shaw P. (2010), Podejmowanie trudnych decyzji. Osiaganie celów dzięki odważnemu działaniu, Oficyna Wolters Kluwer business, Warszawa.

23. Schoemaker P., Kupp S., Howland S. (2013), Strategic Leadership: The Essential Skills, "Harvard Business Review", January - February.

24. Woiceshyn J. (2009), Lessons from "Good Minds": How CEOs Use Intuition, Analysis and Guiding Principles to Make Strategic Decisions, Long Range Planning 42. 